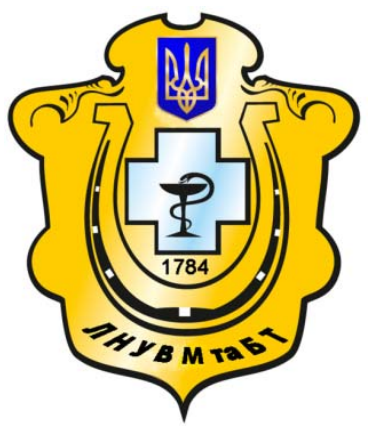

Науковий вісник Львівського національного університету ветеринарної медицини та біотехнологій імені С.3. Гжицького

Scientific Messenger of Lviv National University of Veterinary Medicine and Biotechnologies named after S.Z. Gzhytskyj

doi:10.15421/nvlvet7014

ISSN 2413-5550 print

ISSN 2518-1327 online

$\underline{\text { http://nvlvet.com.ua/ }}$

УДК 619:636.52/.58:616.41+612.112/616.-008.9

\title{
Імуногістохімічна характеристика субпопуляцій лімфоцитів у селезінці курей при вакцинації їх проти інфекційного бронхіту
}

\author{
С.В. Гуральська \\ guralska@ukr.net

\begin{abstract}
Житомирський начіональний агроекологічний університет, Старий бульвар, 7, м. Житомир, 10002, Украӥна
\end{abstract}

У роботі з'ясовано імуногістохімічну характеристику субпопулящій $C D 4^{+}, C D 8^{+}, C D 45 R A^{+}-$лімфоцитів у селезінці курей, вакцинованих проти інфекційного бронхіту. Імуногістохімічні дослідження засвідчили, що зміни кластерів імунних клітин після імунізації мали в селезінці певні особливості. Проведені нами дослідження показали, щуо вакцинація проти інфекційного бронхіту курей на першу, 13 та 33, 83 та 103 добу впливала на зміну відсотка клітин кластера CD4 ${ }^{+}$(хелпери). Так, після введення вакиини на 8 добу спостерігалася тендениія до збільшення його до 9,23 \pm 0,39\% проти 6,91 $\pm 0,26 \%$ y контролі. Але вже на 20 добу відзначалося суттєве збільшення кількості хелперів - 10,07 \pm 0,44\% (p<0,01) проти $8,51 \pm 0,31 \%$ - у контролі. Ранні супресивні прояви реєструвались на 8 добу. Відзначалося різке збільшення кількості CD ${ }^{+}$y дослідній групі, де кількість клітин із ичи маркером перевищувала аналогічні показники в контролі більи, ніж у два рази. Так, при вивченні субпопуляції лімфоцитів з маркером $C D 8^{+}$встановлено вміст їх в контролі - 9,88 $\pm 0,38 \%$; $y$ курей, які отримали вакиину в даний період кількість CD8 $8^{+}$становив 24,99 $\pm 0,46 \%$ ( $\left.p<0,001\right)$. На 8 добу спостерігалася достовірне збільшення кількості CD45RA до 14,22 \pm 0,18\% ( $p<0,001)$, у контрольній групі даний показник становив 9,95 $\pm 0,38 \%$.

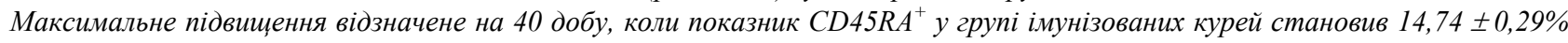
$(p<0,05)$.

Ключові слова: кури, селезінка, лімфочити, $C D 4^{+}, C D 8^{+}, C D 45 R A^{+}$, інфекційний бронхіт, вакцинація, імуногістохімічні дослідження.

\section{Иммуногистохимическая характеристика суб̆опуляций лимфоцитов в селезёнке кур при вакцинации их против инфекционного бронхита}

\author{
С.В. Гуральская \\ guralska@ukr.net \\ Житомирский наииональный агроэкологический университет, \\ Старый бульвар, 7, г. Житомир, 10002, Украина
}

\begin{abstract}
В работе выяснено иммуногистохимическую характеристику субпопуляичй $C D 4^{+}, C D 8^{+}, C D 45 R A^{+}-$лимфоцитов в селезёнке кур, вакцинированных против инфекиионного бронхита. Иммуногистохимические исследования показали, что изменения кластеров иммунных клеток после иммунизации имели в селезёнке определенные особенности. Проведенные нами исследования показали, что вакичиначия против инфекционного бронхита кур на 1, 13, 33, 83 и 103 сутки влияла на изменение процента клеток кластера $C D 4^{+}$(хелперы). Так, после введения вакцины на 8 день наблюдалась тендениия к увеличению его к 9,23 \pm 0,39\% против 6,91 \pm 0,26\% в контроле. Но уже на 20 сутки отмечалось существенное увеличение количества хелперов $(10,07 \pm 0,44 \%$ ( $p<0,01)$ против 8,51 \pm 0,31\% - в контроле. Ранние супрессивное проявления регистрировались на 8 сутки. Отмечалось резкое увеличение количества $C D 8^{+}$в опытной группе, где количество клеток с этим маркером превышала аналогичные показатели в контроле больше, чем в два раза. Так, при изучении субпопуляции лимфоцитов с маркером $C D 8^{+}$установлено содержание их в контроле 9,88 \pm 0,38\%, у кур, которые получали вакцину в данный период,
\end{abstract}

Citation:

Guralska, S.V. (2016). Immunohistochemical characterization of lymphocyte subpopulations in the spleen of chickens after vaccination against infectious bronchitis. Scientific Messenger LNUVMBT named after S.Z. Gzhytskyj, 18, 3(70), 62-66. 
количество $C D 8^{+}$составил 24,99 $\pm 0,46 \%$ ( $<$ 0,001). На 8 день наблюдалась достоверное увеличение количества CD45RA до 14,22 \pm 0,18\% ( $<0,001)$, в контрольной группе данный показатель составлял 9,95 \pm 0,38\%. Максимальное повыииение отмечено на 40-й день, когда показатель CD45R ${ }^{+}$в группе иммунизированных кур составил 14,74 \pm 0,29\% (p < 0,05).

Ключевые слова: куры, селезенка, лимфоциты, $C D 4^{+}, C D 8^{+}, C D 45 R A^{+}$, инфекционный бронхит, вакиинация, иммуногистохимические исследования.

\title{
Immunohistochemical characterization of lymphocyte subpopulations in the spleen of chickens after vaccination against infectious bronchitis
}

\author{
S.V. Guralska \\ guralska@ukr.net
}

\begin{abstract}
Zhytomyr national agroecologycal university, Staryj Boulevard, 7, Zhytomyr, 10002, Ukraine
\end{abstract}

\begin{abstract}
In the work the immunohistochemical characterization of subpopulations of $C D 4^{+}, C D 8^{+}, C D 45 R A^{+}$lymphocytes in the spleen of chickens vaccinated against infectious bronchitis clarified. Immunohistochemical studies have shown that changes in the clusters of immune cells after immunization was certain features in the spleen. Our studies showed that vaccination against infectious bronchitis of chickens in the first, 13 and 33, 83 and 103 day influenced on the change in the percentage of cells in the cluster of CD4 ${ }^{+}$(helper cells). So, after the introduction of the vaccine on the 8 th day, there was a tendency to increase to $9.23 \pm 0,39 \%$ against $6,91 \pm$ $0.26 \%$ in the control group. But at 20 days there was a significant increase in the number of helpers (of $10.07 \pm 0,44 \%(p<0.01)$ against $8.51 \pm 0.31 \%$ in the control. Early supresion manifestations were recorded on 8 th day. There has been a dramatic increase in the number of $C D 8^{+}$in the experimental group, where the number of cells with the marker were higher than in control more than in two times. So, when studying subpopulations of lymphocyte marker CD8 $8^{+}$installed content control for $9.88 \pm 0.38 \%$ in Chicks which received the vaccine in this period, the number of $C D 8^{+}$amounted to $24.99 \pm 0,46 \%(p<0.001)$. On the 8th day there was a significant increase in the number of $C D 45 R A^{+}$to $14.22 \pm 0.18 \%(p<0.001)$, in control group this indicator amounted to $9.95 \pm$ $0.38 \%$ Maximum increase observed on the 40th day, when the CD45R $A^{+}$in the group immunized chickens amounted to $14.74 \pm$ $0.29 \%(p<0.05)$.
\end{abstract}

Key words: chickens, spleen, lymphocytes, $C D 4^{+}, C D 8^{+}, C D 45 R A^{+}$, infectious bronchitis, vaccination, immunohistochemistry.

Вступ

Інфекційний бронхіт птиці реєструється в усіх краінах світу і спричиняе значні економічні збитки промисловим і фермерським птахогосподарствам. Однією $з$ актуальних проблем в птахівництві залишається вибір оптимальних програм імунізації птиці щодо інфекційного бронхіту курей (Parsons et al., 1992; Ignatov, 2003; Seyfi Abad Shapouri et al., 2003; Beato et al., 2005).

Засоби діагностики вірусних хвороб птиці, що використовуються на сьогоднішній день, трудомісткі та $\epsilon$ недостатньо чутливими та специфічними.

Імуногістохімічні дослідження у ветеринарії застосовуються для діагностики інфекційних хвороб, в тому числі інфекційного бронхіту курей (Collisson et al., 2000; Krasnikov et al., 2004; Shutchenko, 2007; Gavrylin et al., 2011; Medvid', 2011). Гаврилін П.М. Прокушенкова О.Г., Недзвецький В.С. (Gavrylin et al., 2011) отримали результати досліджень, які свідчать про те, що імуногістохімічні методи виявлення антигенів вірусних хвороб птиці можуть надати значну інформацію про імуногенні особливості віруса, тропність і кількісний вміст в органах $\mathrm{i}$ тканинах. Ряд авторів використовували імуногістохімічні методи при дослідженні лімфоїдних утворень у курей (Seo and Collisson, 1997; Erf et al., 1998; Yasuda et al., 2002; Olah et al., 2003; Nagy and Olah, 2007; Medvid', 2011). Так, Fredericksen Т. та Gilmour D. (Fredericksen and Gilmour, 1983) показали, що кількість імунокомпетентних T-клітин у селезінці підвищувалася в перший тиждень після вилуплення i продовжувала зростати до 42-ї доби після виведення. Berndt A. та Methner U. (Berndt and Methner, 2001) вивчали розповсюдження та кількість субпопуляцій Т-клітин у сліпій кишці, бурсі Фабриціуса, селезінці після зараження курчат S. typhimurium. У селезінці $\mathrm{CD} 8^{+}$локалізувалися в оболонці періартеріальних лімфатичних судин і в маргінальних зонах. За даними Шутченко П.О. (Shutchenko, 2007) кількість Тлімфоцитів 3 кластерами $\mathrm{CD}^{+}$у селезінці значно зростає у імунізованих курчат, у той час як у інфікованих - стабільніше зростає кількість клітин 3 маркерами $\mathrm{CD}^{+}, \mathrm{CD}^{+}$, TcRl та TcR2. N. Nagi i I. Olah (Nagy and Olah, 2007) при дослідженні пілоричного мигдалика курей, встановили, що $\mathrm{CD}_{45 \mathrm{RA}^{+}-}$ позитивні клітини виявлялися у інтерфолікулярних ділянках та більшість у гермінативних центрах лімфоїдних вузликів.

Перспективність розвитку імуногістохімічних досліджень полягає в тому, що вони поєднують у собі можливості сучасної гістології та імуногістохімічного аналізу на клітинному та тканинному рівнях і дають можливість проводити діагностику у фіксованому матеріалі навіть після тривалого його зберігання (Kiernan, 1981). Імуногістохімічні методи дослідження на теперішній час є невід'ємною частиною наукових досліджень. Застосування імуногістохімії значно розширює можливості морфології як у вивченні етіології, патогенезу патологічних процесів, так і в діагностичній практиці. 
Метою роботи є дослідження морфофункціонального стану селезінки курей при вакцинації проти інфекційного бронхіту. Для досягнення мети необхідно вирішити наступні завдання: 1. визначити вміст, розміщення і кількісне співвідношення субпопуляцій $\mathrm{CD} 4^{+}$- лімфоцитів у селезінці курей різного віку при вакцинації проти інфекційного бронхіту; 2. визначити вміст, розміщення і кількісне співвідношення субпопуляцій $\mathrm{CD}^{+}$- лімфоцитів у селезінці курей різного віку при вакцинації проти інфекційного бронхіту; 3. визначити вміст, розміщення і кількісне співвідно-

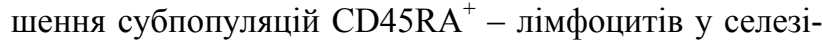
нці курей різного віку при вакцинації проти інфекційного бронхіту.

\section{Матеріал і методи досліджень}

Для досліду було відібрано групу курчат кросу Хайсекс віком 1 доба, вирощених в умовах СТОВ

«Старосолотвинська птахофабрика» Бердичівського району Житомирської області, розділених за принципом аналогів на дві групи по 70 голів в кожній.

Перша група - контрольна, друга - дослідна, курчат якої вакцинували згідно плану щеплень ремонтного молодняку на 1, 13, 33, 83 та 103 добу. При виконанні роботи використовували анатомічні, органометричні, гістологічні та імуногістохімічні дослідження.

Гістологічне дослідження проводили на кафедрі анатомії і гістології факультету ветеринарної медицини Житомирського національного агроекологічного університету. Матеріалом була селезінка курей відібрана від птиці контрольної та дослідних груп на 7 добу після вакцинації, відповідно на 8, 20, 40, 90 та 110 добу. Для проведення гістологічних досліджень застосовували загальноприйняті методи фіксації тканин та виготовлення гістозрізів (Avtandilov, 1990, Goral's'kyj et al., 2005). Імуногістохімічне дослідження проводили в патоморфологічній лабораторії «CSD» м. Київ. На гістологічних зрізах з використанням мишинних моноклональних антитіл (датської фірми DAKO) виявляли субпопуляції лімфоцитів, експресуючих антигенні маркери $\mathrm{CD}^{+}$(Т-хелпери), $\mathrm{CD}^{+}(\mathrm{T}-$ цитотоксичні клітини і нормальні Т-кілери), $\mathrm{CD} 4 \mathrm{RA}^{+}$(В-лімфоцити). За допомогою світлового мікроскопа визначали вміст, розміщення і кількісне співвідношення субпопуляцій. У цих органах підраховували відсоткове співвідношення позитивно фарбованих ділянок або окремих скупчень коричневого кольору до всієї незабарвленої площі зрізу. Обчислення середньостатистичного значення (М), стандартного відхилення середнього (m) та ступеня достовірності (p) здійснювали за допомогою комп'ютерної програми Excel.

\section{Результати та їх обговорення}

Імуногістохімічними дослідженнями встановлено, що в селезінці всіх вікових групах курей субпопуляції лімфоцитів з кластерами $\mathrm{CD}^{+}, \mathrm{CD}^{+}, \mathrm{CD}^{+} 5 \mathrm{RA}^{+}$роз-

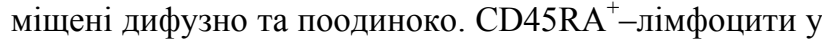
курей 40 добового віку формують біля капсули селезінки «ланцюжки» (рис. 1.). Частина $\mathrm{CD}^{+}, \mathrm{CD}^{+}-$ лімфоцитів у птиці 90-а добового віку розташовані у лімфатичних вузликах, де формують скупчення у вигляді «розеток» (рис. 2.).

Відсоток клітин кластера $\mathrm{CD}^{+}$(хелпери) змінювався в процесі розвитку реакції (рис. 3.). Так, після введення вакцини на 8 добу спостерігалася тенденція до збільшення його до $9,23 \pm 0,39 \%$ проти $6,91 \pm 0,26 \%$ у контролі. Але вже на 20 добу відзначалося суттєве збільшення кількості хелперів $(10,07 \pm 0,44 \%(\mathrm{p}<0,01)$. проти $8,51 \pm 0,31 \%$ - у контролі). На 40 добу різниця між контрольною та дослідною групами була достовірною, рівень лімфоцитів 3 поверхневим маркером $\mathrm{CD}^{+}$помітно зростав до $12,32 \pm 0,43 \%$ (проти контролю 10,02 \pm 0,39\%). Реакція хелперів на вакцинний штам з 90-ї та 110-ї доби починала згасати в порівнянні з попереднім періодом. Так, якщо в курей 90 добового віку дослідної групи вміст $\mathrm{CD}^{+}$становив $11,77 \pm 0,54 \%$, то на 110 добу даний показник становив $-11,04 \pm 0,52 \%$.

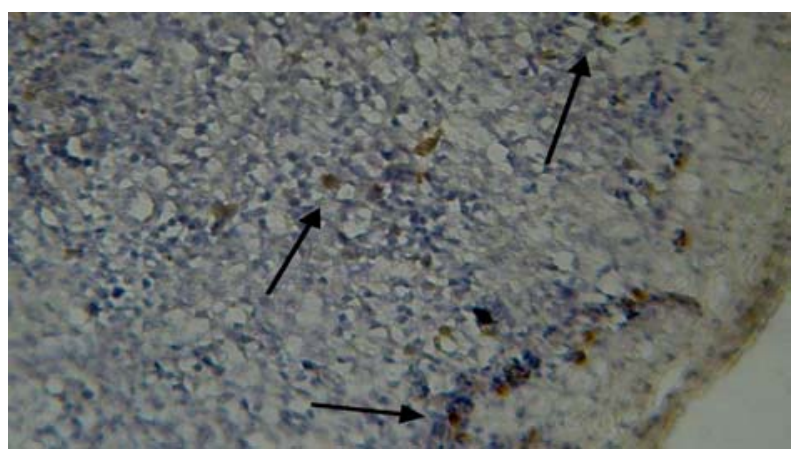

Рис. 1. СД 45RA ${ }^{+}$-лімфоцити у селезінці 40-a добової курки, вакцинованої проти інфекційного бронхіту. X 400

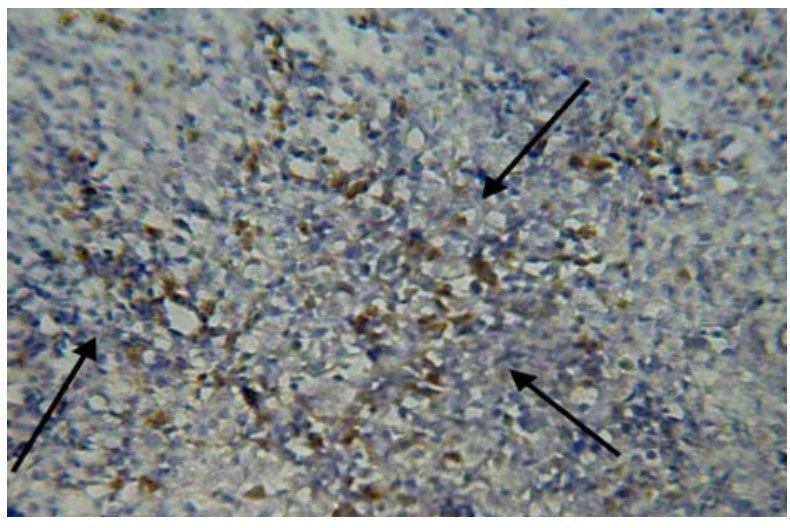

Рис. 2. СД $8^{+}$-лімфоцити у селезінці 90-а добової курки, вакцинованої проти інфекційного бронхіту. $\mathbf{X} 400$

Вивчення субпопуляцій клітин імунітету в селезінці засвідчило, що після вакцинації виявлялись чіткі прояви змін Т-клітин селезінки $\left(\mathrm{CD}^{+}\right)$уже на 8 добу (рис. 4.). Тут також чітко і з високим ступенем достовірності спостерігалася динаміка змін кількості субпопуляції. Ранні супресивні прояви реєструвались на 8 добу коли відсоток вмісту клітин з маркером $\mathrm{CD}^{+}$у групі імунізованих курей, відзначалося різке збіль- 
шення кількості $\mathrm{CD}^{+}$у дослідній групі, де кількість клітин із цим маркером перевищувала аналогічні показники в контролі більше, ніж у два рази. Так, при вивченні субпопуляції лімфоцитів з маркером CD8 ${ }^{+}$ встановлений вміст в контролі $9,88 \pm 0,38 \%$ у курчат, які отримали вакцину в даний період кількість $\mathrm{CD} 8^{+}$ становив 24,99 $\pm 0,46 \%(\mathrm{p}<0,001)$. На 40, 90 добу ознаки посилення $\mathrm{CD}^{+}$в групі імунізованих курчат згасали, і кількість клітин субпопуляції становила $11,88 \pm 0,39 \%(\mathrm{p}<0,05)$ та $12,32 \pm 0,35 \%(\mathrm{p}<0,05)$ відповідно. У контрольній групі даний показник у 40а добовому віці становив - 13,19 $\pm 0,35 \%$ та $13,51 \pm 0,31 \%$ у 90 добовому віці (рис. 4.)

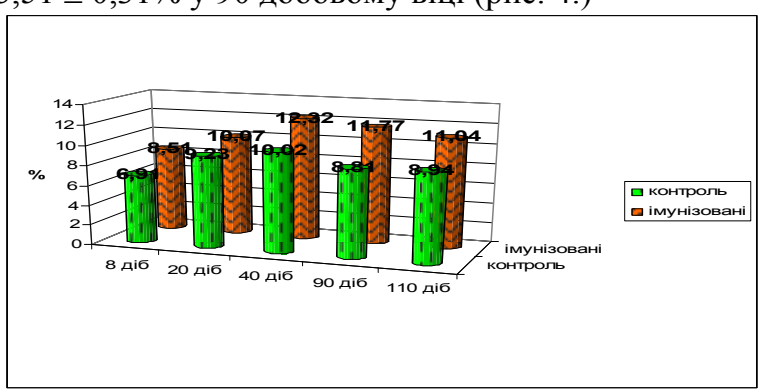

Рис. 3. Динаміка змін субпопуляції лімфоцитів 3 поверхневим маркером $\mathrm{CD4}^{+}$у селезінці курей при вакцинації їх проти інфекційного бронхіту

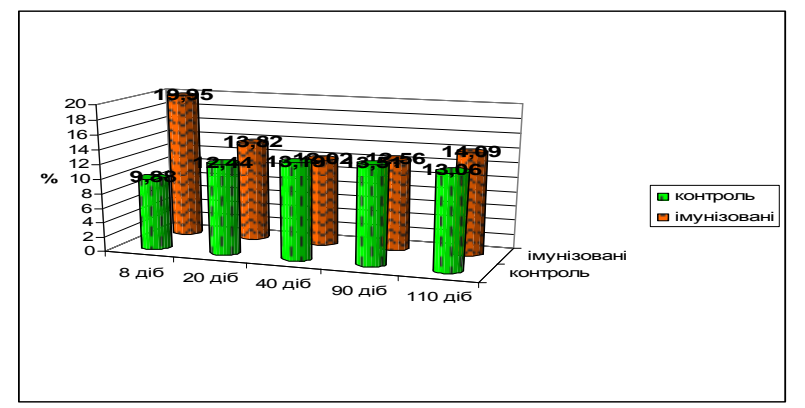

Рис. 4. Динаміка змін субпопуляції лімфоцитів 3 поверхневим маркером $\mathrm{CD8}^{+}$у селезінці курей при вакцинації їх проти інфекційного бронхіту

Наступний період 110 доби характеризувався невеликим збільшенням кількості цих клітин 3 незначним перевищенням порівняно із контрольною групою з $13,06 \pm 0,34 \%$ до $13,95 \pm 0,11 \%(\mathrm{p}<0,05)$ у досліді.

Достовірне збільшення відсоткового вмісту відзначена у субпопуляції $\mathrm{CD}^{4} 5 \mathrm{RA}^{+}$після імунізації курей (рис. 5).

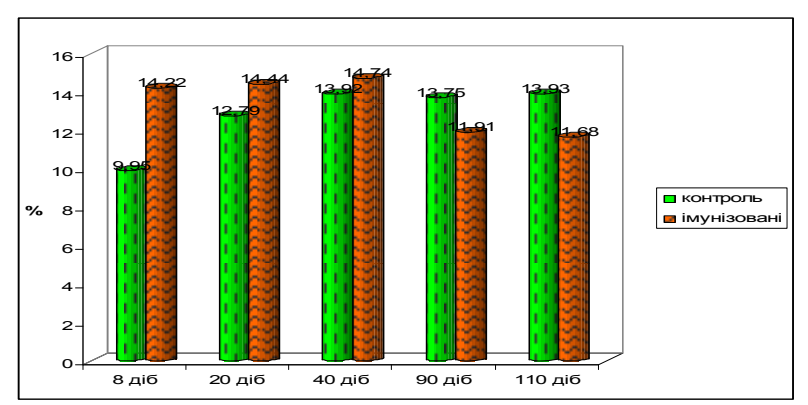

Рис. 5. Динаміка змін субпопуляції лімфоцитів 3 поверхневим маркером $\mathrm{CD}^{2} \mathrm{R} \mathrm{RA}^{+}$у селезінці курей при вакцинації їх проти інфекційного бронхіту
На 8 добу спостерігалася достовірне збільшення

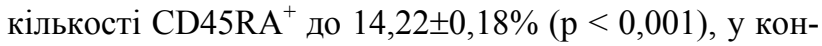
трольній групі даний показник становив 9,95 \pm 0,38\%. Максимальне підвищення відзначене на 40 добу, коли

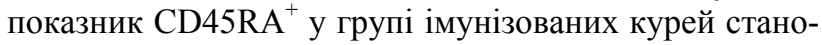
вив $14,74 \pm 0,29 \%(\mathrm{p}<0,05)$. Реакція В-лімфоцитів на вакцинний штам 390 та 110 доби починала згасати в порівнянні з попереднім періодом. Так, якщо в курей 90 добового віку дослідної групи вміст $\mathrm{CD}_{45 \mathrm{RA}}^{+}$ становив $11,91 \pm 0,91 \%(\mathrm{p}<0,01)$, то у контрольній групі даний показник становив - 13,75 $\pm 0,21 \%$ (рис. 5.).

Таким чином, імуногістохімічні дослідження засвідчили, що зміни кластерів імунних клітин після імунізації мали в селезінці певні особливості.

\section{Висновки}

1. Відсоток клітин кластера $\mathrm{CD}^{+}$(хелпери) змінювався в процесі розвитку реакції. Так, після введення вакцини на 8 добу спостерігалася тенденція до збільшення його до 9,23 \pm 0,39\% проти 6,91 $\pm 0,26 \%$ у контролі. Але вже на 20 добу відзначалося суттєве збільшення кількості хелперів (10,07 $\pm 0,44 \%$ (p < $0,01)$ проти $8,51 \pm 0,31 \%$ - у контролі.

2. Вивчення субпопуляцій клітин імунітету в селезінці засвідчило, що після вакцинації виявлялись чіткі прояви змін Т-клітин селезінки $\left(\mathrm{CD}^{+}\right)$уже на 8 добу. Тут також чітко і з високим ступенем достовірності спостерігалася динаміка змін кількості субпопуляції.

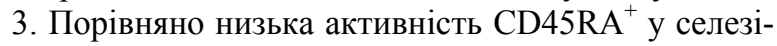
нці курей дослідної групи з 90 по 110 добу свідчила про відносно слабку участь цього органу в продукції гуморальних антитіл при вакцинації проти інфекційного бронхіту курей.

Перспективи подальших досліджень. Планується провести імуногістохімічні дослідження органів імуногенезу та кровотворення при інфекційному бронхіті курей.

\section{Бібліографічні посилання}

Ignatov, M.M. (2003). Naukove obg'runtuvannja vakcynoprofilaktyky infekcijnogo bronhitu kurej: avtoref. dys. na zdobuttja nauk. stupenja kand. vet. nauk: spec. 16.00.08 «Epizootologija ta infekcijni hvoroby». UAAN. In-t eksperym. i klinich. vet. medycyny. 22 (in Ukrainian).

Parsons, D., Ellis, M.M., Cavanagh, D., Cook J.K.A. (1992). A «new» strain of infectious bronchitis virus infecting domestic fowl in Great Britain. Veterinary Record. 130, 493-494.

Seyfi Abad Shapouri, M.R., Mayahi, M., Assasi, K., Charkhakar, S. (2003). A survey of the prevalence of infectious bronchitis virus type 4/91 in Iran. Acta Veterinaria Hungarica. 52, 163-166.

Beato, M.S., Battisti, C.De., Terregino, C., Drago A. (2005). Evidence of circulation of a Chinese strain of infectious bronchitis virus (QXIBV) in Italy. The Veterinary Record. 156-172. 
Gavrylin, P.M. Prokushenkova, O.G., Nedzvec'kyj, V.S. (2011). Metodychni osoblyvosti zastosuvannja imunogistohimichnogo analizu dlja diagnostyky virusnyh hvorob ptyci [Elektronnyj resurs] (in Ukrainian).

Krasnikov, G.A. Shutchenko, P.A., Berndt, A. (2004). Primenenie immunogistohimicheskih metodov issledovanija pri izuchenii immuniteta zhivotnyh. III konferencija Vseukraïns'kogo tovaristva veterinarnih patologiv, 21-23 kvitnja 2004 r. Harkiv. 4(1), 35-38 (in Ukrainian).

Medvid', K.O. (2011). Vyvchennja dynamiky nakopychennja subpopuljacij imunokompetentnyh klityn u selezinci kurchat za eksperymental'nogo zarazhennja virusom nyz'kopatogennogo grypu ptyci. Problemy zooinzhenerii' ta veterynarnoi' medycyny : zb. nauk, prac' Harkivs'koi' derzhavnoi' zooveterynarnoi' akademii'. 1, 23, 2, 61-64 (in Ukrainian).

Shutchenko, P.O. (2007). Imunogistohimichna diagnostyka ta ocinka klitynnogo imunitetu pry sal'monel'ozi kurej: avtoref. dys. na zdobuttja nauk. stupenja kand. vet. nauk: spec. 16.00.03 «Veterynarna mikrobiologija ta virusologija». Harkiv. 21 (in Ukrainian).

Cytotoxic, T.W., Collisson, E., Pei, J., Dzielawa, J., Seo S.H. (2000). lymphocytes are critical in the control of infectious bronchitis virus in poultry. Dev. Comp. Immunol. 24, 187-200.

Seo, S.H., Collisson, E.W. (1997). Specific cytotoxic T lymphocytes are involved in in vivo clearance of infectious bronchitis virus. J. Virol. 71, 5173-5177.

Yasuda, M., Tanaka, S., Arakawa, H. [et al.] (2002). A comparative study of Gut- Associated Lymphoid Tis- sue in calf and chicken. The Anatomical Record. 266, 207-217.

Erf, G.F., Bottje, W.G., Bersi, T.K., Headrick M.D. (1998). Effects of dietary vitamin $\mathrm{E}$ on the immune system in broilers: Altered proportions of CD4 T cells in the thymus and spleen. Poultry Science. 77, 529537.

Nagy, N., Olah, I. (2007). Pyloric tonsil as a novel gutassociated lymphoepithelial organ of the chicken. Journal of Anatomy. 211(3), 407-411.

Olah, I., Nagy, N., Magyar, A. (2003). Esophageal tonsil: a Novel gut-associated lymphoid organ. Poultry Science. 82, 767-770.

Fredericksen, T.L., Gilmour, D.G. (1983). Ontogeny of conA and PHA responses of chicken blood cells in MHC-compatible lines 6(3) and 7(2). J. Immunol. 130, 2528-2533.

Berndt, A., Methner, U. (2001). Gamma-delta T-cell response of chickens after oral administration of attenuated and non-attenuated Salmonella typhimurium strains. Vet. Immunol. Immunopathol. 78, 143-161.

Kiernan, J.A. (1981). Histological and histochemical metods: theory and practice. N.Y.: Pergamon Press. 81 .

Avtandilov, G.G. (1990). Medicinskaja morfometrija: [rukovodstvo]. M.: Medicina (in Russian).

Goral's'kyj, L.P., Homych, V.T., Konons'kyj O.I. (2005). Osnovy gistologichnoi' tehniky i morfofunkcional'ni metody doslidzhennja u normi ta pry patologii': [navch. posibnyk]. Zhytomyr: Polissja (in Ukrainian).

Стаття надійшла до редакиії 25.09.2016 